\title{
Benefit of Lactose Concentration between Goat's Milk and Commercialized Powder Milk
}

\author{
Nur Sofuwani ZA' ${ }^{1}$, Siti Aslina $\mathbf{H}^{1^{*}}$ and Siti Mazlina MK $^{2}$
}

${ }^{1}$ Department of Chemical and Environmental Engineering, Faculty of Engineering, Universiti Putra Malaysia, Selangor, Malaysia ${ }^{2}$ Department of Food and Process Engineering, Faculty of Engineering, Universiti Putra Malaysia, Selangor, Malaysia

\begin{abstract}
Even though goat's milk naturally has lower lactose than cow's milk ( $4.39 \%$ compared to $4.51 \%)$, when it's consumed in a large amount, those intolerant to lactose may suffer several inconvenient symptoms, such as bloating, nausea, and diarrhoea. Previous study had established that a high level of lactose removal from goat's milk could be attained by 10 KDa sized ultrafiltration (UF) membrane. Hence, the concentrated goat's milk obtained from the UF process and five local brands of commercial milk powder were compared in terms of nutrition facts. Lactose concentration as important nutrition is evaluated for the quality and the competitiveness between the products. While, proximate analysis was used as part of method to determine the chemical composition in the goat's milk, including moisture, protein, fat, ash, and carbohydrate. Then, the composition of the reconstituted concentrated powder milk and five others commercialized milk which homogenized with water was analysed by HPLC to determine the lactose concentration. As a finding, concentrated milk contained $5.63 \mathrm{~g}$ per $100 \mathrm{ml}$ lactose concentration, which ranked at the second lowest concentration in the range of 2.81 to $7.91 \mathrm{~g}$ per $100 \mathrm{ml}$, proved that it is similar and comparable in standard as to commercial milk.
\end{abstract}

Keywords: Membrane; Ultrafiltration; Goat's milk; Proximate; Lactose concentration; Powder milk

\section{Introduction}

Ultrafiltration (UF) has molecular weight cut-off (MWCO) in the range of $1-500 \mathrm{KDa}$ and corresponds to a nominal pore diameter of 1 $\mathrm{nm}$ to $100 \mathrm{~nm}[1,2]$. The cut-off means molecular weight of the smallest molecule that cannot pass through the membrane. The pore size of the UF membrane is selected based on the size of the molecules being separated. In other words, larger molecules, such as proteins, fat, and carbohydrates, are fully or partially retained; depending on the pore size of the membrane used [3]. UF was mainly used for producing low lactose dairy products from cow's milk [4-6].

Hence, applying UF membrane with MWCO greater than $10 \mathrm{KDa}$ would lead to increased transmission or loss of essential milk proteins, while using UF membrane with pore size smaller than $5 \mathrm{KDa}$ may cause inefficiency in the UF process due to a significant reduction in lactose transmission. That is why the most common cut-off in dairy standard is $10 \mathrm{KDa}$. Meanwhile, membrane sizes within 6 to $9 \mathrm{KDa}$ may have operated in a different pattern as UF membrane commonly has a definite or a diffuse separation limit. Membranes with a sharp cutoff separates lower molecular weight, while membranes with a diffuse cut-off allows permeation of some higher molecular weight solute and retains some lower molecular weight [3].

Fouling and concentration polarization (CP) on membrane surface during goat's milk processing which deteriorating the flux and gave negative impact on product yield are the major problems in the dairy industry. Until today, the issue concerning how to overcome fouling in cross-flow hollow fibre ultrafiltration unit is still debated due to the complex composition characteristic of milk that consists of proteins, minerals, lactose, and fat which contributes to the major foulants during the dairy UF process $[7,8]$. A recent study had proved that processing parameters condition of $0.18 \mathrm{~L} / \mathrm{min}$ feed flow-rate and 0.55 bars transmembrane pressure (TMP) gave the best condition in $10 \mathrm{KDa}$ with UF membrane as it produced goat's milk with lowest lactose rejection and higher operating flux [9]. Hence, this paper focuses on evaluating the effects of this parameter on nutrition facts and lactose concentration.
The scope of work is that in order to ensure the comparability of low lactose goat's milk produced with other commercialized milk, all the milk samples were compared after atomization by spray-drying in terms of lactose percentage range and nutritional composition. Nonetheless, this research was not extended to determine the amount of protein content in concentrated milk.

\section{Materials and Methodology}

\section{Conversion of liquid retentate milk into powder milk}

The concentrated goat's milk from $10 \mathrm{KDa}$ sized UF membrane had to undergo the spray-drying process, as portrayed in Figure 1, where it turned the liquid milk into milk powder. Lab-scale spray-dryer (Niro A/S, Mobile Minor, US) was used with air inlet and outlet temperatures at $150^{\circ} \mathrm{C}$ and $75^{\circ} \mathrm{C}$, respectively. The optimum temperature for the growth of most of the bacteria was around $40^{\circ} \mathrm{C}$, and hence, the experiments were carried out at above $40^{\circ} \mathrm{C}$. The additive used was AAA maltodextrin (MDX) in the range of $15 \% \mathrm{w} / \mathrm{w}$ [10]. The spraydried powder was stable during storage in vacuum sealed pack. The concentrated powder milk obtained from the fractionation was then reconstituted with warm water at $50^{\circ} \mathrm{C}$. The standard formulation was used by adding and mixing $55 \mathrm{~g}$ of powder milk into $190 \mathrm{ml}$ of warm water, $55 \mathrm{~g} / 190 \mathrm{ml}$ weight per volume or around one standard cupful [11]. The hot stirrer plate, along with the magnetic stirrer, played an important part in homogenizing the milk sample. Five other brands of commercialized milk powder were also homogenized.

*Corresponding author: Siti Aslina H, Department of Chemical and Environmental Engineering, Faculty of Engineering, Universiti Putra Malaysia, 43400 Serdang, Selangor, Malaysia, Tel: 03-8946292, Fax: 03-86567120; E-mail: aslina@upm.edu.my

Received June 15, 2017; Accepted July 05, 2017; Published July 12, 2017

Citation: Nur Sofuwani ZA, Siti Aslina H, Siti Mazlina MK (2017) Benefit of Lactose Concentration between Goat's Milk and Commercialized Powder Milk. J Food Process Technol 8: 682. doi: 10.4172/2157-7110.1000682

Copyright: () 2017 Nur Sofuwani ZA, et al. This is an open-access article distributed under the terms of the Creative Commons Attribution License, which permits unrestricted use, distribution, and reproduction in any medium, provided the original author and source are credited. 


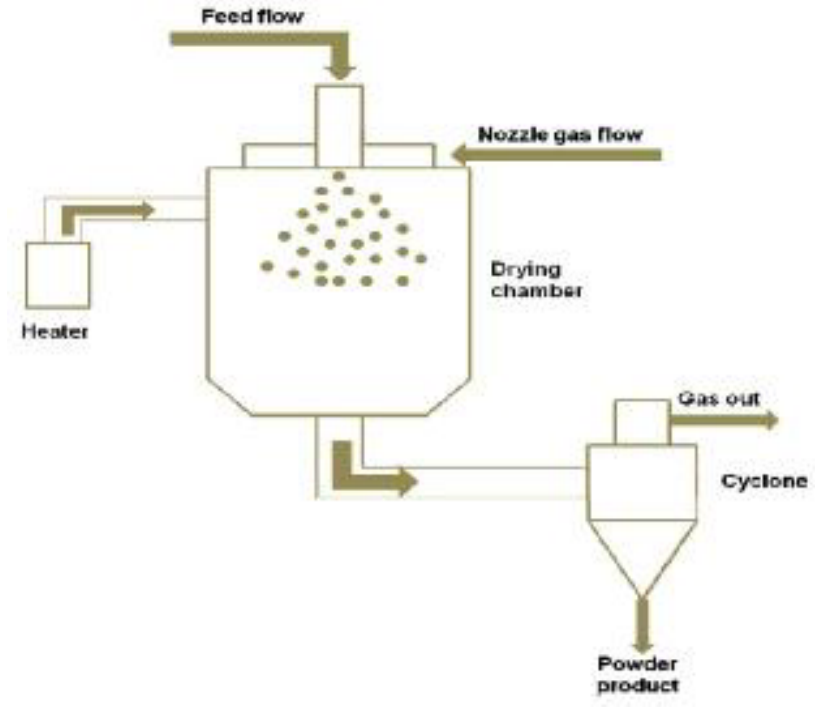

Figure 1: Schematic diagram of spray-drier (Niro A/S, Mobile Minor, US) (Food Engineering Laboratory, UPM) $\left(\mathrm{T}_{i}: 150^{\circ} \mathrm{C}, \mathrm{T}_{0}: 75^{\circ} \mathrm{C}, 15 \% \mathrm{w} / \mathrm{w} \mathrm{MDX}\right)$.

\section{Proximate analysis}

Proximate analysis was used in order to determine the chemical composition in the concentrated goat's milk, including moisture, protein, fat, ash, and carbohydrate [12] in Bioreactor Laboratory, Department of Process and Food Engineering, Universiti Putra Malaysia. The moisture content was measured in the laboratory using an infrared moisture analyzer (MX-50, A \& D, Japan). Meanwhile, protein analysis was determined by using Kjeltec instruments (FOSS, Hillerod, Denmark), while fat analysis was determined via Soxtec extraction systems (Soxtec 2050, Foss Electric, Denmark) and ash content was indicated through the processes of ashing the powder milk sample by using furnace (Carbolite). Lastly, the carbohydrate content was measured by hundred minus total summations of other proximate.

\section{Crude fat determination}

The Soxtec method (Soxtec 2050, Foss Electric, Denmark) involved a direct solvent extraction. An empty solvent beaker was weighed. One gram $( \pm 0.01)$ of pre-dried sample was weighed on a filter paper. The filter paper with sample was placed into a pre-dried extraction thimble, and was covered with cotton wool. The thimble was transferred into the Soxtec extraction system, and then, about $125 \mathrm{ml}$ of petroleum ether was added in the solvent beaker. Mask and gloves were used as petroleum ether is a volatile substance. The Soxtec apparatus allowed the ether to soak into the sample. The sample was remained cool during extraction. The sample was held in porous thimbles, crucibles, filter paper, etc. The process was time-consuming. The unit was completed after 1.5 hours. The oven was pre-heat at $100^{\circ} \mathrm{C}$ for $10 \mathrm{~min}$. After that, a towel was used to take the solvent beaker out. The solvent beaker with extracted fat was dried in an air oven at $100^{\circ} \mathrm{C}$ for $30 \mathrm{~min}$, cooled in a desiccator for about $5 \mathrm{~min}$, and then weighed.

Equation (1), (2) and (3) are the calculations used to calculate the fat content [11]:

$$
\begin{aligned}
& \text { Weight of fat }=(\text { beaker }+ \text { fat })-\text { beaker } \\
& \% \text { fat wet basis }=\left(\frac{\text { weight of fat }}{\text { original sample weight }}\right) \times 100
\end{aligned}
$$

$$
\% \text { fat drybasis }=\left(\frac{\text { weight of fat }}{\text { dried sampleweight }}\right) \times 100
$$

\section{Protein determination}

Kjeltec instrument (FOSS, Hillerod, Denmark) was used to determine the protein content in milk [11]. Protein determination in food solely depends on the amount of nitrogen. The three stages of the Kjeltec methods are digestion, distillation, and titration. Approximately $1 \mathrm{~g}$ of sample was weighed into the digestion tube followed by 2 tablets of Kjeltab (copper tablets with $3.5 \mathrm{~g} \mathrm{~K}_{2} \mathrm{SO}_{4}+0.4 \mathrm{~g}$ $\mathrm{CuSO}_{4} 5 \mathrm{H}_{2} \mathrm{O}$ ). $\mathrm{CuSO}_{4}$ was added during the digestion process to act as a catalyst and to increase the efficiency of sulfuric acid digestibility. 12 $\mathrm{ml}$ sulfuric acid (R\&M; $98.08 \mathrm{~g} / \mathrm{mol}$ ) was added and the mixture was digested (FOSS Digestor Auto Lift) at $420^{\circ} \mathrm{C}$ for one hour. The amount of nitrogen was determined via sample digestion by using sulfuric acid $\left(\mathrm{H}_{2} \mathrm{SO}_{4}\right)$ to form ammonium sulfate. The amount of ammonium to ammonia was measured by using $\mathrm{NaOH}$ solution via distillation. The ammonia released was captured through titration by the excess $\mathrm{HCl}$ solution to produce ammonium chloride while producing ammonium borate when captured using boric acid (weak acid). Then, crude protein content of the sample was obtained using Tecator Kjeltec protein analyser (FOSS, Hillerod, Denmark) by titration.

\section{Moisture content determination}

Moisture content of concentrated powder milk was determined by using infrared moisture analyzer (MX-50, A \& D, Japan). Heating with infrared can be considered for sample of flour form or grind sample. Infrared moisture analyzer is an instrument that comprises of a balance and an infrared lamp that measure against the distance of sample to lamp. The sample was weighed $5 \mathrm{~g}$ and the temperature was set to $130^{\circ} \mathrm{C}$. Moisture loss percentage was then directly determined.

\section{Ash content determination}

Ash content was indicated by gravimetric method according to AOAC [12] through the processes of ashing the powder milk sample by using a muffle furnace (Carbolite) at a very high temperature, $575^{\circ} \mathrm{C}$ for five hours. First, the weight of cool crucibles was recorded after preheating at $100^{\circ} \mathrm{C}$. Two grams of the sample was weighed into the crucible and the weight was recorded. If the sample had been moist, it would be placed in an oven at $100^{\circ} \mathrm{C}$ and allowed to dry for an hour. Then, the sample was allowed to cool for a while before it was transferred to furnace at a temperature of $575^{\circ} \mathrm{C}$ for $5 \mathrm{~h}$. After five hours, the furnace was turned off and it was opened after the temperature dropped to $50^{\circ} \mathrm{C}$. The door was opened carefully to avoid losing ash that may be fluffy. Using a tong, the sample was placed into a desiccator and then, allowed to cool to room temperature. Lastly, the weight was recorded.

Equation (4) was used to calculate ash content [10]:

Total ash (ondrybasis), \% by mass $=\left(\frac{M_{1}-M_{0}}{\text { Samplewt }}\right) \times 100$

Where,

$M_{1}=$ mass in $\mathrm{g}$, of the crucible with ash

$\mathrm{M}_{0}=$ mass in $\mathrm{g}$, of the empty crucible

\section{Carbohydrate content determination}

Each gram of carbohydrate has four calories. Carbohydrate was calculated by 100 minus the sum of other proximates. The values for moisture, fat, protein, and ash contents were added and this value was 
subtracted from 100 to give the carbohydrate content. The calculation used to determine the total carbohydrate included lactose percentage by weight is as in equation (5) [10]:

Total carbohydrate $\%$ by wt. $=100-(\mathrm{P}+\mathrm{F}+\mathrm{M}+\mathrm{A})$

Where,

\section{$\mathrm{P}=$ Percent by mass of protein}

$\mathrm{F}=$ Percent by mass of fat

$\mathrm{M}=$ Percent by mass of moisture

$\mathrm{A}=$ Percent by mass of ash

\section{Results and Discussion}

\section{Production of concentrated powder milk}

The concentrated milk from $10 \mathrm{KDa}$ sized UF membrane was spray dried as shown in Figure 2 prior to proximate analysis and lactose concentration analysis. This helps in preservation, as powder milk has a longer shelf life than liquid milk, and does not need refrigeration due to low moisture content [13]. The powder retentate milk was then compared with other commercialized milk products.

To ensure the quality of goat's milk is maintained, the concentrated powder milk from $10 \mathrm{KDa}$ membrane was then analysed in terms of nutritional composition and compared with five other reference samples from commercialized milk products labelled as A, B, C, D, and E. the proximate composition was defined by fat, protein, moisture, ash, and carbohydrate content. Table 1 represents the proximate composition

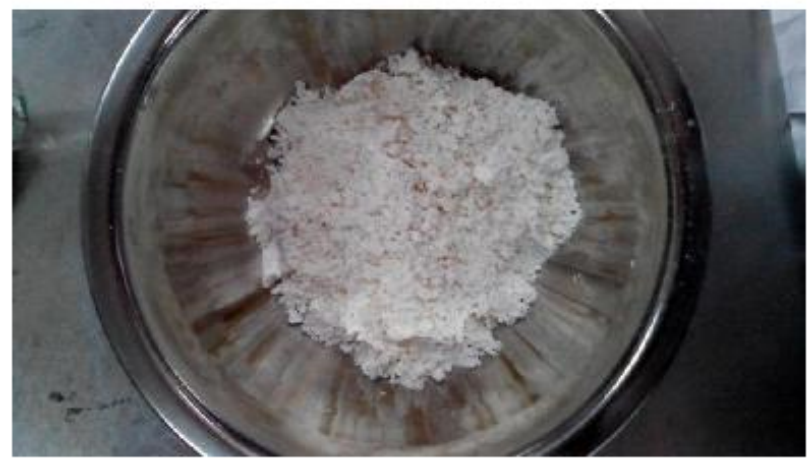

Figure 2: Goat's milk concentrated powder. result. The proximate composition of retentate milk shows the means of total fat $8.12 \% \pm 0.09$, total protein $17.44 \% \pm 0.13$, total moisture $3.30 \% \pm 0.04$, total ash $26.90 \% \pm 0.37$, and total carbohydrate $44.24 \%$. Based on Table 1, the total fat content in retentate milk obtained from fractionation process is the highest due to utilization of raw goat's milk, which is $8.12 \pm 0.09$. Moreover, the fat content in $\mathrm{A}, \mathrm{B}, \mathrm{C}, \mathrm{D}$, and $\mathrm{E}$ milk is $1.54 \pm 0.07,0.50 \pm 0.14,3.44 \pm 0.20,2.79 \pm 0.14$, and $1.05 \pm 0.07$, respectively. Lipids in milk are important in the aspects of nutrition, physical, and sensory characteristics of milk products [14]. The main lipid component of goat's milk is triacylglycerol's (TAG), which is about $97 \%$, including a great number of esterified fatty acids [15]. The lipid component also contains simple lipids such as diacylglycerols, monoacylglycerols, and cholesterol esters, and complex lipids such as phospholipids [14]. The protein content of retentate milk is the second highest among other samples which is $17.44 \pm 0.13$. Meanwhile, the protein content for $\mathrm{A}, \mathrm{B}, \mathrm{C}, \mathrm{D}$, and $\mathrm{E}$ milk was $17.97 \pm 0.14,15.64 \pm$ $0.06,6.09 \pm 0.06,15.41 \pm 0.02$, and $13.58 \pm 0.08$, respectively as in Table 1. There are two groups of milk proteins which are casein and whey proteins. The caseins constitute $80 \%$ of the proteins and are classified as $\alpha$ s1, as $2, \beta$ and $\kappa$-caseins, while the major $20 \%$ refer to whey proteins namely $\beta$-lactoglobulin and $\alpha$-lactalbumin [16].

The moisture content in retentate milk is second lowest which is $3.30 \pm 0.04$, while the moisture content percentage for $\mathrm{A}, \mathrm{B}, \mathrm{C}, \mathrm{D}$, and $\mathrm{E}$ was in the range of 2.60 to $4.87 \%$, marked as $4.87 \pm 0.04,4.74 \pm 0.13$, $4.16 \pm 0.02,2.60 \pm 0.02$, and $4.67 \pm 0.15$, respectively. The ash content is generally recognized as a measure of quality for the assessment of the functional properties of foods [17]. Based on Table 1, the ash content of retentate milk is the second highest, which is $26.90 \pm 0.37$. While for $\mathrm{A}, \mathrm{B}, \mathrm{C}, \mathrm{D}$, and $\mathrm{E}$, the ash content percentage was $22.74 \pm 0.03$, $21.78 \pm 0.06,23.98 \pm 0.14,29.46 \pm 0.22$, and $26.19 \pm 0.21$, respectively. This is because goat's milk has been reported to have higher content of potassium, chloride, calcium, phosphorus, selenium, zinc, and copper than cow's milk [18]. The main role of carbohydrates in diet is to produce energy. Each gram of carbohydrates provides us with 4.2 calories. Carbohydrates also act as a food store. Based on Table 1, the total carbohydrate of retentate milk is the lowest, which is $44.24 \%$, while for sample A is $52.88 \%, \mathrm{~B}$ is $57.35 \%$, C is $66.47 \%$, D is $47.34 \%$, and $\mathrm{E}$ is $54.52 \%$. This is because lactose is a major carbohydrate in milk, and most importantly, retentate milk has lower lactose compared to other milk tested. Energy calculation was determined by multiplying the value of nutritional content of carbohydrate, protein, and fat with their conversion factor, which is $4 \mathrm{kcal}$ for carbohydrate and protein, $9 \mathrm{kcal}$ for fat, and that $1 \mathrm{Kcal}$ is equal to $4.2 \mathrm{~kJ}$. Serving size suggestion was $230 \mathrm{ml}$ per serving. Table 1 represents the energy content in all

\begin{tabular}{|c|c|c|c|c|c|c|c|}
\hline \multicolumn{8}{|c|}{ Nutritional Information } \\
\hline \multicolumn{2}{|c|}{ Sample } & Concentration & A & B & C & D & $E$ \\
\hline \multirow[t]{2}{*}{ Carbohydrate } & Mean $\pm \mathrm{SD}(\%)$ & 44.24 & 52.88 & 57.35 & 66.47 & 47.34 & 54.52 \\
\hline & Per $100 \mathrm{ml}$ & $17.70 \mathrm{kcal}$ & $21.15 \mathrm{kcal}$ & $22.94 \mathrm{kcal}$ & $26.59 \mathrm{kcal}$ & $18.94 \mathrm{kcal}$ & $21.80624 \mathrm{kcal}$ \\
\hline \multirow[t]{2}{*}{ Protein } & Mean \pm SD (\%) & $17.44 \pm 0.13$ & $17.97 \pm 0.14$ & $15.64 \pm 0.06$ & $6.09 \pm 0.06$ & $15.41 \pm 0.02$ & $13.58 \pm 0.08$ \\
\hline & Per $100 \mathrm{ml}$ & $6.98 \mathrm{kcal}$ & $7.19 \mathrm{kcal}$ & $6.25 \mathrm{kcal}$ & $2.43 \mathrm{kcal}$ & $6.16 \mathrm{kcal}$ & $5.4328 \mathrm{kcal}$ \\
\hline \multirow[t]{2}{*}{ Fat } & Mean \pm SD (\%) & $8.12 \pm 0.09$ & $1.54 \pm 0.07$ & $0.50 \pm 0.14$ & $3.44 \pm 0.20$ & $2.79 \pm 0.14$ & $1.05 \pm 0.07$ \\
\hline & Per $100 \mathrm{ml}$ & $7.31 \mathrm{kcal}$ & $1.39 \mathrm{kcal}$ & $0.45 \mathrm{kcal}$ & $3.10 \mathrm{kcal}$ & $2.51 \mathrm{kcal}$ & $0.94221 \mathrm{kcal}$ \\
\hline Moisture & Mean \pm SD (\%) & $3.30 \pm 0.04$ & $4.87 \pm 0.04$ & $4.74 \pm 0.13$ & $4.16 \pm 0.02$ & $2.60 \pm 0.02$ & $4.67 \pm 0.15$ \\
\hline Ash & Mean \pm SD (\%) & $26.90 \pm 0.37$ & $22.74 \pm 0.03$ & $21.78 \pm 0.06$ & $23.98 \pm 0.14$ & $29.46 \pm 0.22$ & $26.19 \pm 0.21$ \\
\hline $\begin{array}{c}\text { Energy }(1 \mathrm{kcal}= \\
4.2 \mathrm{~kJ})\end{array}$ & Mean \pm SD (\%) & $31.98 \mathrm{kcal}=134.32 \mathrm{~kJ}$ & $29.73 \mathrm{kcal}=124.85 \mathrm{~kJ}$ & $\begin{array}{c}29.64 \mathrm{kcal}= \\
124.50 \mathrm{~kJ}\end{array}$ & $32.12 \mathrm{kcal}=134.90 \mathrm{~kJ}$ & $\begin{array}{c}27.61 \mathrm{kcal}= \\
115.95 \mathrm{~kJ}\end{array}$ & $\begin{array}{l}28.18 \mathrm{kcal} \\
=118.36 \mathrm{~kJ}\end{array}$ \\
\hline Lactose & Per $100 \mathrm{ml}$ & 5.63 & 7.79 & 7.91 & 6.68 & 7.27 & 2.81 \\
\hline
\end{tabular}

Table 1: Nutritional composition in different type of milk. 
Citation: Nur Sofuwani ZA, Siti Aslina H, Siti Mazlina MK (2017) Benefit of Lactose Concentration between Goat's Milk and Commercialized Powder Milk. J Food Process Technol 8: 682. doi: 10.4172/2157-7110.1000682

type of milk analysed per $100 \mathrm{ml}$. Thus, the energy content in retentate milk per serving is the second highest with $134.32 \mathrm{~kJ}$, A is $124.85 \mathrm{~kJ}, \mathrm{~B}$ is $124.50 \mathrm{~kJ}, \mathrm{C}$ is $134.90 \mathrm{~kJ}, \mathrm{D}$ is $115.95 \mathrm{~kJ}$, and $\mathrm{E}$ is $118.36 \mathrm{~kJ}$.

The composition of reconstituted retentate powder milk and five others commercialized milk homogenized with water was analysed by HPLC to determine the lactose concentration. Table 1 states the range of lactose concentration in different brands of milk in Malaysia. From the data obtained, lactose concentration is in the range of 2.81 to $7.91 \mathrm{~g}$ per $100 \mathrm{ml}$, with concentrated milk is $5.63 \mathrm{~g}$, A is $7.79 \mathrm{~g}, \mathrm{~B}$ is $7.91 \mathrm{~g}, \mathrm{C}$ is $6.68 \mathrm{~g}, \mathrm{D}$ is $7.27 \mathrm{~g}$, and $\mathrm{E}$ is $2.81 \mathrm{~g}$. Concentrated milk with a concentration of $5.63 \mathrm{~g}$ per $100 \mathrm{ml}$ is in the range of lactose concentration given that it is in the rank of the second lowest amount of lactose concentration. Interestingly, sample A and B which claimed to be lactose fee cow's milk obviously had higher lactose content which is $7.79 \mathrm{~g}$ and $7.91 \mathrm{~g}$ per $100 \mathrm{ml}$, respectively compared to the other samples. Meanwhile, whole goat's milk in sample C contained higher lactose $(6.68 \mathrm{~g}$ per $100 \mathrm{ml})$ than concentrated milk $(5.63 \mathrm{~g}$ per $100 \mathrm{ml})$ obtained from this study. On the other hand, sample D contained quite a high proportion of lactose $(7.27 \mathrm{~g}$ per $100 \mathrm{ml})$ which may be due to soy milk fortification that was subjected with sugar carbohydrate for the organoleptic importance. Finally, sample E from almond milk contained the lowest lactose concentration with $2.81 \mathrm{~g}$ per $100 \mathrm{ml}$ due to the fact that lactose is a carbohydrate sugar exists in mammal milk only. This has proven that the concentrated milk obtained from this study is a low-lactose goat's milk and hence can be claimed as comparable standard or similar to other types of commercial milk.

\section{Conclusion}

Concentrated goat's milk from $10 \mathrm{KDa}$ UF membrane size had been subjected to a comparison with other types of commercialized milk after atomization. Moreover, concentrated goat's milk with lactose concentration of $5.63 \mathrm{~g}$ per $100 \mathrm{ml}$ was in the range of lactose concentration comparison with commercial milk. It can be concluded that a high degree of lactose removal from goat's milk could be achieved using MWCO $10 \mathrm{KDa}$ cross-flow hollow fibre ultrafiltration system in producing low-lactose milk, which is as comparable as commercial milk.

\section{Acknowledgement}

Acknowledgement is due to Universiti Putra Malaysia for granting the financial support for my Masters studies in UPM, under Geran Universiti Putra Malaysia, GP-IPS/2013/9392300. Special thanks also extended to Department of Process and Food Engineering, Department of Chemical and Environmental Engineering, Department of Food Science and Technology, UPM, and Department of Veterinary Services, Alor Gajah, Melaka for providing facilities and equipment for this study.

\section{References}

1. Kulkarni SS, Funk EW, Li NM (2001) Ultrafiltration: Introduction and definitions. Membrane handbook, Norwell. Massachusetts, USA.

2. Zall $R$ (1987) Accumulation and quantification of on-farm ultra-filtered milk: The California experience. Milchwissenschaft 42: 98-100.

3. Mulder J (1991) Basic principles of membrane technology. Kluwer academic publishers, The Netherlands.

4. Patel RS, Reuter H, Prokopek D, Sachdeva S (1991) Manufacture of low lactose powder using ultrafiltration technology. Food Sci Technol 24: 338-340.

5. Edelsten D, Meersohn M, Friis P, Nielsen EW, Sørensen KL, et al. (1983) Production of skim milk powder with lactose content reduced by ultrafiltration. Milchwissenschaft 38: 261-263.
6. Kosikowski F (1979) Low lactose yoghurts and milk beverages by ultrafiltration. J Dairy Sci 62: 41-46.

7. Cheryan M (1998) Ultrafiltration and microfiltration handbook. Technomic Publishing Company Inc, Lancaster, PA, USA

8. Zeman LJ, Zydney AL (1996) Microfiltration and ultrafiltration: Principles and applications. Marcel Dekker Inc, New York.

9. Sofuwani N, Aslina S, Mazlina S (2016) Separation of lactose from raw goat's milk by cross-flow hollow fibre ultrafiltration membrane. Int Food Res J 23: 209219.

10. Wang W, Zhou W (2010) Effect of maltodextrins on water adsorption and glass transition of spray dried soy sauce powders.

11. Savaiano DA, Levitt MD (1987) Milk intolerance and microbe-containing dairy foods. J Dairy Sci 70: 397-406.

12. AOAC (2000) Official methods of analysis. Association of official analytical chemists. Washington, DC, USA.

13. Westergaard V (2010) Milk powder technology. GEA Niro, Copenhagen, Denmark.

14. Park YW, Juarez M, Ramos M, Haenlein GFW (2007) Physico-chemical characteristics of goat and sheep milk. Small Rumin Res 68: 88-113.

15. Cerbulis J, Parks OW, Farrell HM (1982) Composition and distribution of lipids of goats' milk. J Dairy Sci 65: 2301-2307.

16. Slacanac V, Bozanic R, Hardi J, Rezessyne J, Lucan M, et al. (2010) Nutritional and therapeutic value of fermented caprine milk. Int J Dairy Technol 63: 171-189.

17. Hofman PJ, Vuthapanich S, Whiley AW, Klieber A, Simons DH (2002) Tree yield and fruit minerals concentrations influence "Hass" avocado fruit quality. Sci Hort J 92: 113-123.

18. Saini AL, Gill RS (1991) Goat milk: An attractive alternate. Indian Dairyman 42: $562-564$ 